\title{
Regulation of the plasminogen activator activity and inflammatory environment via transforming growth factor-beta regulation of sperm in porcine uterine epithelial cells
}

\author{
Su-jin Kim ${ }^{1}$, Hee-Tae Cheong ${ }^{2}$ and Choon-keun Park ${ }^{1, *}$ \\ ${ }^{1}$ College of Animal Life Sciences, Kangwon National University, Chuncheon 24341, Korea \\ ${ }^{2}$ College of Veterinary Medicine, Kangwon National University, Chuncheon 24341, Korea
}

Received November 13, 2020

Revised December 4, 2020

Accepted December 5, 2020

\section{*Correspondence \\ Choon-keun Park \\ E-mail: parkck@kangwon.ac.kr}

ORCID

https://orcid.org/0000-0003-2786-8814
ABSTRACT The aims of the present study were to confirm that regulation of the PA and environment via TGF- $\beta$ regulation of sperm by Percoll-separated in porcine uterine epithelial cells. And, it was performed to identify the cytokines (TGF- $\beta 1,2$ and 3, TGF- $\beta$ receptor1 and 2; interleukin, IL-6, IL-8) and PA-related genes (urokinase-PA, UPA; tissuePA, tPA; PA inhibitor, PAl; uPA-receptor, UPAR) by spermatozoa. The experiment used porcine uterus epithelial cells (pUECs) and uterine tissue epithelial cells, Boar sperm were separated by discontinuous Percoll density gradient (45/90\%), and tissues were co-incubated with spermatozoa, followed by real-time PCR. PA activity was measured of sperm by discontinuous Percoll density gradient (45/90\%) for 24 hours. To measure viability and acrosome damage of sperm double stained propidium iodide (PI) and SYBR14 or FITC-PNA were used. In results, binding ratio of Percoll-separated sperm was found no differences, but sperms isolated from 90\% Percoll layer reduced PA activity $(p<0.05)$. when co-cultured sperm selected Percoll in porcine uterus tissues epithelial cells, $90 \%$ layer sperm increased TGF- $\beta$ R1, contrastively tPA and PAI-1 in comparison with control $(p<0.05) .45 \%$ sperm was decreased the expression of UPA $(p<0.05)$. TGF- $\beta$ decreased PA activity in the supernatant collected from pUECs $(p<0.05)$. Especially, The group including UPA, PAI-1 were induce sperm intact, while it was reduced in sperm damage when compared to control $(p<0.05)$. Also, there was no significant difference group of tPA and $\mathrm{TPA}+\mathrm{I}$ in the dead sperm and acrosome damage compared to control. The expression of tPA and PAl showed a common response. Percoll-separated spermatozoa in 90\% layer reduced tPA and IL-related gene mRNA expression. Thus, Percoll-sparated sperm in $90 \%$ layer show that it can suppress inflammation through increased expression of TGF- $\beta$ and downregulation of PA and IL in epithelial cells compared to $45 \%$ layer Percoll.

Keywords: cytokine, interleukin, plasminogen activator, porcine uterus tissue epithelial cell, spermatozoa, transforming growth factor-beta (TGF- $\beta$ ) 


\section{INTRODUCTION}

In uterine of numerous mammalian species, be occurred alteration such as menstruation, implantation, embryo development, pregnancy and childbirth for the reproduction. As physiological changes such as menstruation and pregnancy occur generate protein breakdown, inflammatory reactions and fibrinolysis occur. Also, Most physiological changes occur after sperm reaches the uterus and is fertilized, and the uterus has been studied as a growth organ in which sperm moves through the passage connecting the cervix and the oviduct and the embryo is implanted (Kotilainen et al., 1994; Waberski et al., 2006; López-Úbeda et al., 2017). It has been reported that in the cervix or oviduct other than the uterus, it is possible to select sperm by forming a reservoir for sperm and forming a net (Marey et al., 2020). Though an immune response to select sperm in the uterus occurs, Only the maternal immune response has been studied (Kotilaninen et al., 1994), and the research on the sperm's own response is insignificant.

Porcine are multiparous animal with a short uterin body and a longus uterin horn. Until the sperm reach the fallopian tube, the maternal immune response to the sperm and semen external substance occurs in the uterus (Marey et al., 2020). Also, pigs have a large amount of semen and are mainly breed a domestic animals in comparison with other mammals, so artificial insemination is done more than natural mating. Thus, the selection of the sperm easier than other animals, the semen and sperm extender except for sperm can affext the uterine immune response. Percoll concentration gradient method can divide sperm according to motility, and divided sperm can increase fertilization rate (Matás et al., 2003). The separate sperm has increased cleavage, blastocyst and pregnancy rates than sperm washed with bovine serum albumin (BSA) and unwashed (Matás et al., 2003).

Transforming growth factor-beta (TGF- $\beta$ ) was a cytokine that accounts for the largest proportion of semen (Barranco et al., 2019), it can suppress maternal immunity together with sperm. It is secreted by several cells and plays an important role in the immune system. TGF- $\beta$ was of functions such as uterine development, follicular development, and embryonic development in female reproduct system (Li, 2014). It was reported that TGF- $\beta 1$ regulates cell growth by inhibiting proliferation and inducing death in rabbit uterine epithelial cells (Rotello et al., 1991). In addition, other study confirmed that TGF- $\beta$ ignificantly increased DNA fragmentation and apoptosis in the endometrium epithelial cells (Rotello et al., 1991; Wada et al., 1996).

The plasminogen/plasmin system (PLG-PLA system) functions as one of the most important extracellular protease systems in vivo, it participates in different processes related to the degradation of protein matrix, cell migration, tissue remodeling, angiogenesis, and inflammation (Castrllino and Ploplis, 2005; Arssina and Mukhametova, 2014). The inactive plasminogen is converted into plasmin through a complex process by specific activators, plasminogen activators (PAs). This includes the urokinasetype plasminogen activator ( $\mathrm{uPA}$ ) or the tissue-type (tPA), and it is regulated by plasminogen activator inhibitors type 1 (PAI-1), type 2 (PAI-2), and type 3 (PAI-3), as well as the uPA-specific receptor (UPAR) (España et al., 1991; Castellino and Ploplis, 2005). In bovine and porcine, plasminogen and plasmin did not affect sperm, but there is also a study that when IVF of plasminogen was added, penetration, monospermy, sperm/oocyte and sperm attached to zona pellucida all significantly decreased (Grullón et al., 2013). The uPA, plasminogen activator, has been studied to increase fertility in horses (Wang et al., 2006). Active uPA was reported to have a positive correlation with semen volume, total sperm count, and sperm motility when ejaculated (Martinez-Soto et al., 2018).

The previous study confirmed that when sperm isolated with Percoll from epithelial cells was treated, sperm isolated with $90 \%$ Percoll decreased TGF- $\beta$, thereby reducing PA activity. There is a limit to only uterine epithelial cells (pUECs), so the experiment was performed on uterine tissue epithelial cells. In order to confirm the importance of selection of porcine sperm and the importance of sperm attached to epithelial cells, it was hypothesized that sperm could be involved in the secretion of TGF- $\beta$ to protect itself by attaching to porcine uterine epithelial cells to regulate PA. Therefore, the purpose of this study was to confirm the effect of TGF- $\beta$ on the change of PA in porcine uterine epithelial cells and endometrial tissue, and to confirm the change of TGF- $\beta$ and PA by sperm. 


\section{MATERIALS AND METHODS}

\section{Animal ethics}

All 1 experimental procedures were approved by the institutional animal care and use committee (IACUC) of Kangwon National University (No: KIACUC-19-015) were approved by the Animal Experimental Ethics Committee of Kangwon National University.

\section{Isolation and culture of pUECs and uterine tissue epithelial cell}

A porcine uterus $(n=20)$ was collected from a local slaughterhouse and transported to the laboratory on ice within $2 \mathrm{~h}$. The estrous cycle of the uterus was identified by measuring the diameters of the follicles (up to $6 \mathrm{~mm}$ in diameter for the antral follicles) and uterus at the preovulatory phase 4-5. The uterus was washed twice with Hank's Balanced Salt Solution (HBSS) containing 0.1\% (w/ v) BSA and the uterine horn was separated from the surrounding tissues. After incising the longitudinal axis of the uterine horn and fixing it with a pin, cut only the endometrium of the uterine horn with a scalpel, cut it into a uniform size of $1.5 \times 1.5 \mathrm{~cm}$, and put it in a 6-well plate. It was pre-incubated in serum-free DMEM/F-12 at $38.5^{\circ} \mathrm{C}$ and $5 \% \mathrm{CO}_{2}$ for 18 hours. Then, co-culture with sperm was performed.

The pUECs was used 4 uterus, and the scraped and collected. in Dulbecco's Modified Eagle's Medium/Ham's F-12 nutrient mixture (DMEM/F-12; Welgene, Daegu, Republic of Korea) containing 66 units/mL collagenase type IV with gentle shaking at $37^{\circ} \mathrm{C}$ for $30 \mathrm{~min}$. Blood cells were then removed using Tris-NH4 solution and the remaining pUECs were cultured in DMEM/F-12 supplemented with $10 \%(\mathrm{v} / \mathrm{v}) \mathrm{FBS}, 1 \%(\mathrm{v} / \mathrm{v})$ penicillin-streptomycin solution (Hyclone, Logan, UT, USA) and $1 \mu \mathrm{g} / \mathrm{mL}$ amphotericin B (Sigma-Aldrich, St. Louis, MO, USA). Culture medium was replaced every $48 \mathrm{~h}$ and cells were cultured to a confluency of $80-90 \%$. The pUECs were then passaged into 6-well and 12 -well plates at $1 \times 10^{5}$ cells $/ \mathrm{mL}$ and $0.5 \times 10^{5}$ cells/ $\mathrm{mL}$, respectively.

\section{Preparation and co-incubation of boar sperm}

In order to separate boar sperm according to its functional integrity, the discontinuous Percoll gradient method was used. The boar semen were purchased 5 times from Gumbo (Gumbo, Wonju, Republic of Korea), A total of 25 samples were used. The sperm were used according to the manufacturer's method of Percoll (GE Healthcare bio-Sciences ABSE, Uppsala, Sweden). Namely, different concentrations of Percoll solution (45/90\%) were prepared and $2 \mathrm{~mL}$ of $45 \%$ Percoll solution was carefully layered over $2 \mathrm{~mL}$ of $90 \%$ Percoll solution. Subsequently, $500 \mu \mathrm{L}$ of the sperm sample was slowly dropped onto the $45 \%$ Percoll layer followed by centrifugation at $740 \times \mathrm{g}$ for 30 min. Spermatozoa from the different Percoll layers were collected and washed twice using Modena B $(30.0 \mathrm{~g} / \mathrm{L}$ glucose, $2.50 \mathrm{~g} / \mathrm{L}$ sodium citrate, $2.25 \mathrm{~g} / \mathrm{L}$ EDTA, $5.00 \mathrm{~g} /$ $\mathrm{L}$ tris, $1.00 \mathrm{~g} / \mathrm{L}$ sodium bicarbonate, $2.50 \mathrm{~g} / \mathrm{L}$ citric acid, $0.30 \mathrm{~g} / \mathrm{L}$ gentamicin sulfate and $0.05 \mathrm{~g} / \mathrm{L}$ cysteine). Prepared sperm were pre-incubated at $1 \times 10^{6}$ cells $/ \mathrm{mL}$ with the pUECs in 12-well plates using serum-free DMEM/ $\mathrm{F}-12$ containing $0.1 \%(\mathrm{w} / \mathrm{v}) \mathrm{BSA}$ at $38.5^{\circ} \mathrm{C}$ for $30 \mathrm{~min}$. After pre-incubation, unbound sperm were removed and the spermatozoa bound to pUECs were co-incubated for a further $24 \mathrm{~h}$. To analyze only tissue epithelial cells, the epithelial cell surface was immersed in Trizol reagent (TaKaRa, Shiga, Kusatsu, Japan) to extract only the epithelial cells, and then stored in a refrigerator at $-80^{\circ} \mathrm{C}$ for real-time PCR.

\section{cDNA synthesis and real-time PCR}

The total RNA (500 ng) from tissue epithelial cells was synthesized using the PrimeScript ${ }^{\mathrm{TM}} 1$ st strand cDNA Synthesis Kit (Takara, Shiga, Kusatsu, Japan) according to the manufacturer's instructions for cDNA. In brief, $1 \mu \mathrm{g}$ of total RNA was incubated with $5 \mu \mathrm{M}$ Oligo dT primer and $1 \mathrm{mM}$ dNTP mixture at $65^{\circ} \mathrm{C}$ for $5 \mathrm{~min}$, after which it was immediately cooled on ice. Following this, RNA was mixed with 1 units/ $\mu \mathrm{L}$ RNase inhibitor and 10 unit $/ \mu \mathrm{L}$ RTase, and this mixture was incubated for cDNA synthesis at $42^{\circ} \mathrm{C}$ for $1 \mathrm{~h}$. Synthesized cDNA was quantified using a NanoDrop 2000 (Thermo Scientific Nanodrop, Wilmington, DE, USA) and was diluted to a concentration of 50 $\mathrm{ng} / \mu \mathrm{L}$ for downstream real time (RT)- PCR analysis. All the primers used in this study were designed using Primer BLAST (https://www.ncbi.nlm.nih.gov/tools/primer-blast/ index.cgi?LINK_LOC=BlastHome; Table 1). Thunderbird SYBR qPCR mix (Toyobo, Osaka, Japan) was used for RTPCR and cDNA amplification was performed following these three steps: denaturation at $95^{\circ} \mathrm{C}$ for $15 \mathrm{~s}$, annealing at $60^{\circ} \mathrm{C}$ for $30 \mathrm{sec}$, and extension at $72^{\circ} \mathrm{C}$ for $30 \mathrm{~s}$, for 40 cycles. Relative levels of mRNA expression were nor- 
Table 1. Sequences and condition of primer sequence used to real-time PCR

\begin{tabular}{|c|c|c|c|}
\hline Gene & Primer sequence $\left(5^{\prime} \rightarrow 3^{\prime}\right)$ & Product size (bp) & Accession number \\
\hline Transforming growth factor-beta 1 (TGF- $\beta 1$ ) & $\begin{array}{l}\text { F: ACCTGCAAGACCATCGACA } \\
\text { R: GCTCCGGTTCGACACTTTCC }\end{array}$ & 196 & NM_214015.2 \\
\hline Transforming growth factor-beta 2 (TGF- $\beta 2$ ) & $\begin{array}{l}\text { F: GCGCTACATCGACAGCAAAG } \\
\text { R: TGCAGCAGGGACAGTGTAAG }\end{array}$ & 143 & XM_021064293.1 \\
\hline Transforming growth factor-beta 3 (TGF- $\beta 3$ ) & $\begin{array}{l}\text { F: CTGTGCGTGAATGGCTCTTG } \\
\text { R: CTTAAGTCGCCCCAGGTCTC }\end{array}$ & 185 & NM_214198.1 \\
\hline Transforming growth factor-beta receptor 1 (TGF- $\beta R 1)$ & $\begin{array}{l}\text { F: AAGCCACCATCTGGCCTTG } \\
\text { R: TGGCACTCGATGGTGAATGA }\end{array}$ & 132 & NM_001038639.1 \\
\hline Transforming growth factor-beta receptor 1 (TGF- $\beta R 2)$ & $\begin{array}{l}\text { F: TGGCTGTCTGGAGGAAGAATG } \\
\text { R: ATCCGTGGTAGGCGATCTTG }\end{array}$ & 78 & XM_021071493.1 \\
\hline Urokinase-type plasminogen activator (uPA) & $\begin{array}{l}\text { F: TGCATCGAACTGTGGCTGTC } \\
\text { R: GACCGTTCCCCTCAAAGCAG }\end{array}$ & 146 & NM_213945 \\
\hline Tissue-type plasminogen activator (tPA) & $\begin{array}{l}\text { F: CAGCCGCTGCACTTCAAAAC } \\
\text { R: GTGTACACACCCGGAACGTC }\end{array}$ & 222 & NM_214054 \\
\hline Urokinase-type plasminogen activator receptor (UPAR) & $\begin{array}{l}\text { F: GCACACATGGGAAGGAGGTG } \\
\text { R: CGAGGCACAGGAAGCACATT }\end{array}$ & 214 & XM_003127198 \\
\hline Plasminogen activators inhibitor type-1 (PAI-1) & $\begin{array}{l}\text { F: CACCGCCTCTTCCACAAGTC } \\
\text { R: ATGCTCAGAGTGTTGCCGTG }\end{array}$ & 149 & NM_213910 \\
\hline Interleukin-6 (IL-6) & $\begin{array}{l}\text { F: ACAAAGCCACCACCCCTAAC } \\
\text { R: CGTGGACGGCATCAATCTCA }\end{array}$ & 185 & NM_214399.1 \\
\hline Interleukin-8 (IL-8) & $\begin{array}{l}\text { F: AGTGCAGAACTTCGATGCCA } \\
\text { R: TGGGGTCCACTCTCAATCAC }\end{array}$ & 95 & NM_213867.1 \\
\hline Glyceraldehyde-3-phosphate dehydrogenase (GAPDH) & $\begin{array}{l}\text { F: CATGGTTCACGCCCATCACA } \\
\text { R: TCCCGCCAACATCAAATGGG }\end{array}$ & 170 & NM-001206359 \\
\hline
\end{tabular}

A

(1) Non-sperm

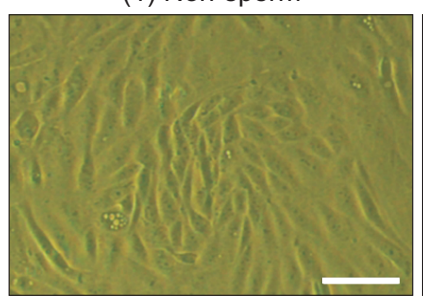

(2) $45 \%$ Percoll

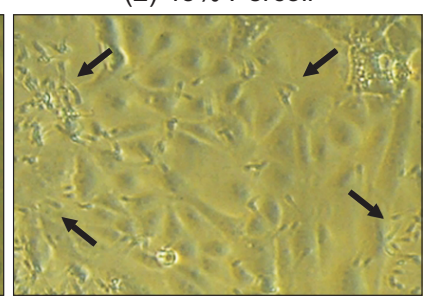

(3) $90 \%$ Percoll

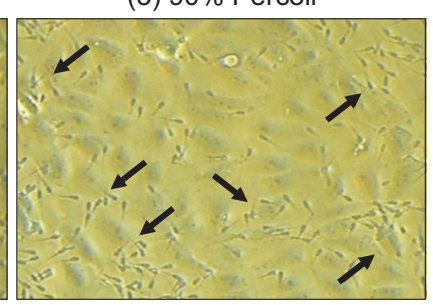

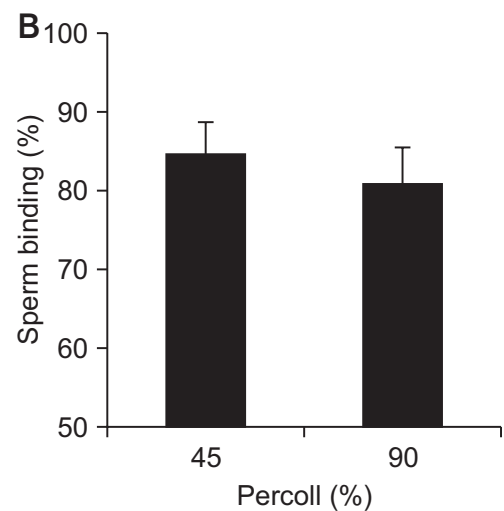

Fig. 1. (A) Binding of boar spermatozoa separated by discontinuous Percoll density gradient (45/90\%) to porcine uterine epithelial cells. Sperm bound to epithelial cells are indicated by black arrows. Scale bar : $50 \mu \mathrm{m}$. (B) Change of binding of divided sperm from Percoll in porcine uterine epithelial cells (pUECs).

malized to glyceraldehyde-3-phosphate dehydrogenase (GAPDH), and quantified using the $2^{-\Delta \Lambda} \mathrm{Ct}$ method.

\section{Measurement of PA activity}

Collected culture medium $(20 \mu \mathrm{L})$ was dispensed into a 96-well microplate and mixed with $30 \mu \mathrm{L}$ of a plasminogen working solution $(2.5 \mu \mathrm{g} /$ well plasminogen; SigmaAldrich, St. Louis, MO, USA). The solution was incubated at $37^{\circ} \mathrm{C}$ for $1 \mathrm{~h}$. After incubation, $200 \mu \mathrm{L}$ of substrate buffer [0.18 mM Z-L-Lys-SBzl hydrochloride, $0.22 \mathrm{mM} \mathrm{5,5^{ \prime }}$ -dithiobis-(2-nitrobenzoic acid), and 0.01\% Triton X-100] was added to the sample and further incubated at $37^{\circ} \mathrm{C}$ for $30 \mathrm{~min}$. PA activity was determined by the absorbance at the $405 \mathrm{~nm}$ using a microplate reader. There were triplicates for each measure. 


\section{Flow cytometry (FACs) method of sperm}

To confirmation sperm damage by PAs, FACs analysis was performed on sperm into uPA, tPA, uPA+I, tPA+I, and I groups. Sperm were collected in the $90 \%$ layer by the Percoll concentration gradient, and $5 \times 10^{6}$ sperm were

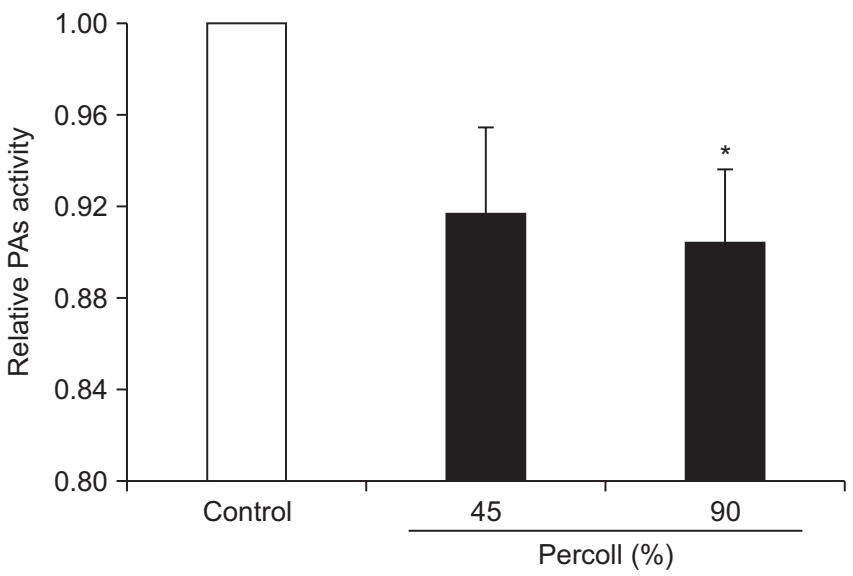

Fig. 2. Change of plasminogen activiter activity by different quality of boar spermatozoa in porcine uterine epithelial cells (pUECs). Asterisk indicates significant difference $(p<0.05)$. used for each treatment group. Also, All PAs were treated at a concentration of $100 \mathrm{pg} / \mathrm{mL}$. Flow cytometric analysis of sperm was performed by double staining using $2 \mathrm{uM}$ of Propidium iodide (PI) and $6 \mathrm{nM}$ of SYBR-14 or $3 \mathrm{uM}$ Arachis hypogaea (FITC-PNA) lectin for each treatment group. Data analysis was performed using the Flowing software 2 program using the dot plat method.

\section{Statistical analysis}

All data were analyzed using the Statistical Analysis System software (SAS, version 9.4). Data are represented as the means \pm standard error of the mean (SEM). Student t-test preceded by GLM for results of PCR was used to compare differences between treatment group. PA activity data were analyzed using Duncan's multiple range test. A value of $p<0.05$ was considered statistically significant.

\section{RESULTS}

\section{Sperm treatment in porcine uterine epithelial cells}

Fig. 1 was confirmed that sperm divided by Percoll was
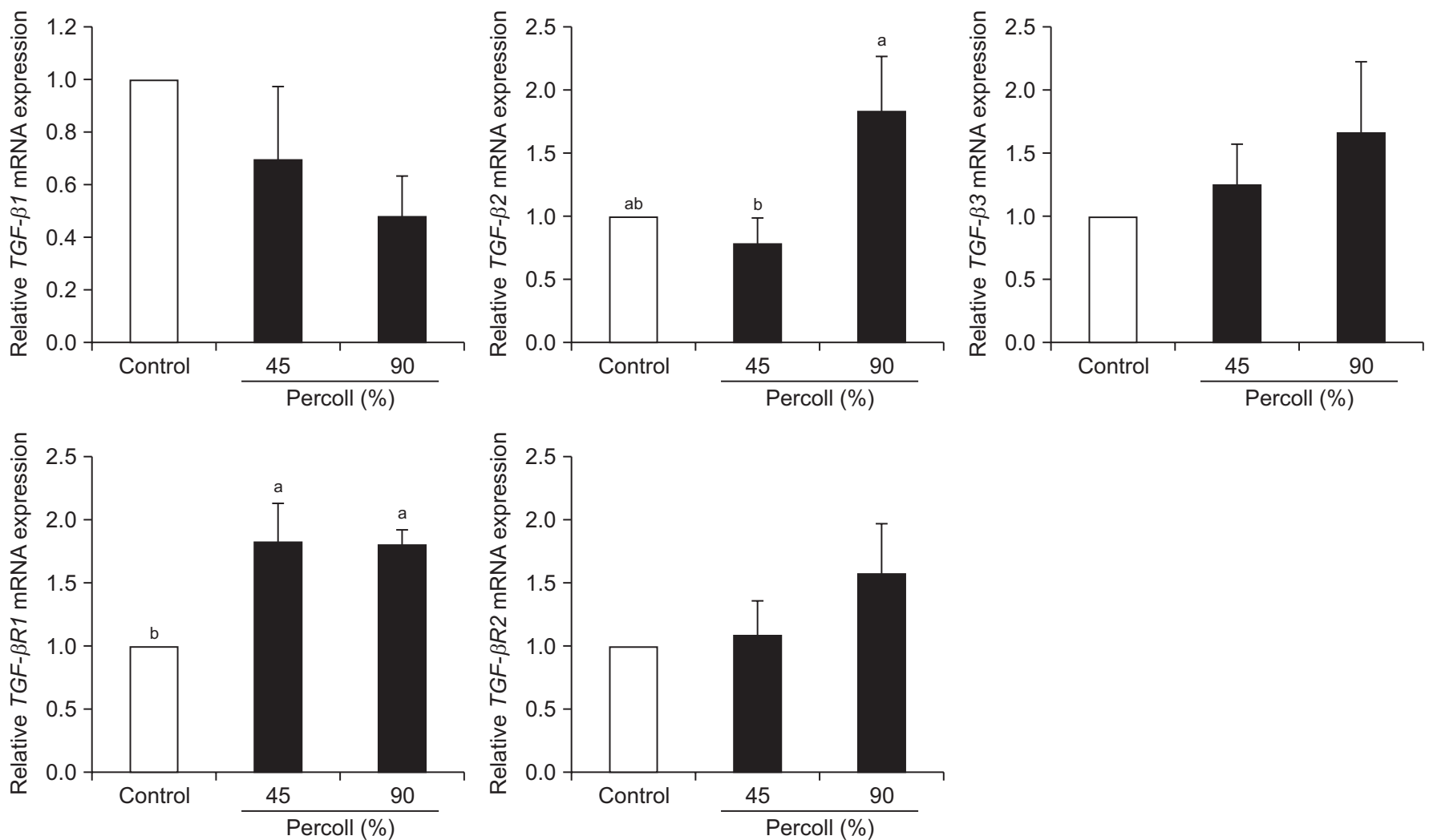

Fig. 3. The expression of transforming growth factor- beta isoform (TGF- $\beta$ 1, 2, and 3 ) and TGF- $\beta$ receptor (TGF- $\beta$ R1 and 2 ) mRNA in porcine endometrial uterine tissue epithelial cells bound with boar spermatozoa separated by discontinuous Percoll density gradient. ${ }^{\mathrm{a}, \mathrm{b}}{ }^{\mathrm{indi}}{ }^{-}$ cates significant difference $(p<0.05)$. 
co-cultured on hog pUECs for 30 minutes, and after removing sperm that could not adhere through washing, the sperm adhesion rate was confirmed. There was no significant difference in adhesion rates between sperm in $45 \%$ Percoll layer and sperm divided in $90 \%$ layer (Fig. 1). When PA activity was measured in the culture medium after treatment of sperm according to the characteristics, the PA activity was decreased in the $90 \%$ layer separated by Percoll compared to the control group $(p<0.05)$. On the other hand, there was no significant difference in the sperm group affected by the $45 \%$ layer (Fig. 2).

\section{The role of sperm in porcine uterine tissue epithelial cells}

When the expression of TGF- $\beta$ by sperm was also confirmed in porcine uterine tissue epithelial cells, sperm isolated at $90 \%$ Percoll significantly increased TGF- $\beta 2$ and TGF- $\beta$ R1. Similarly, sperm in the $45 \%$ layer increased TGF- $\beta$ R1 ( $p<0.05$, Fig. 3 ). In addition, when the expres-
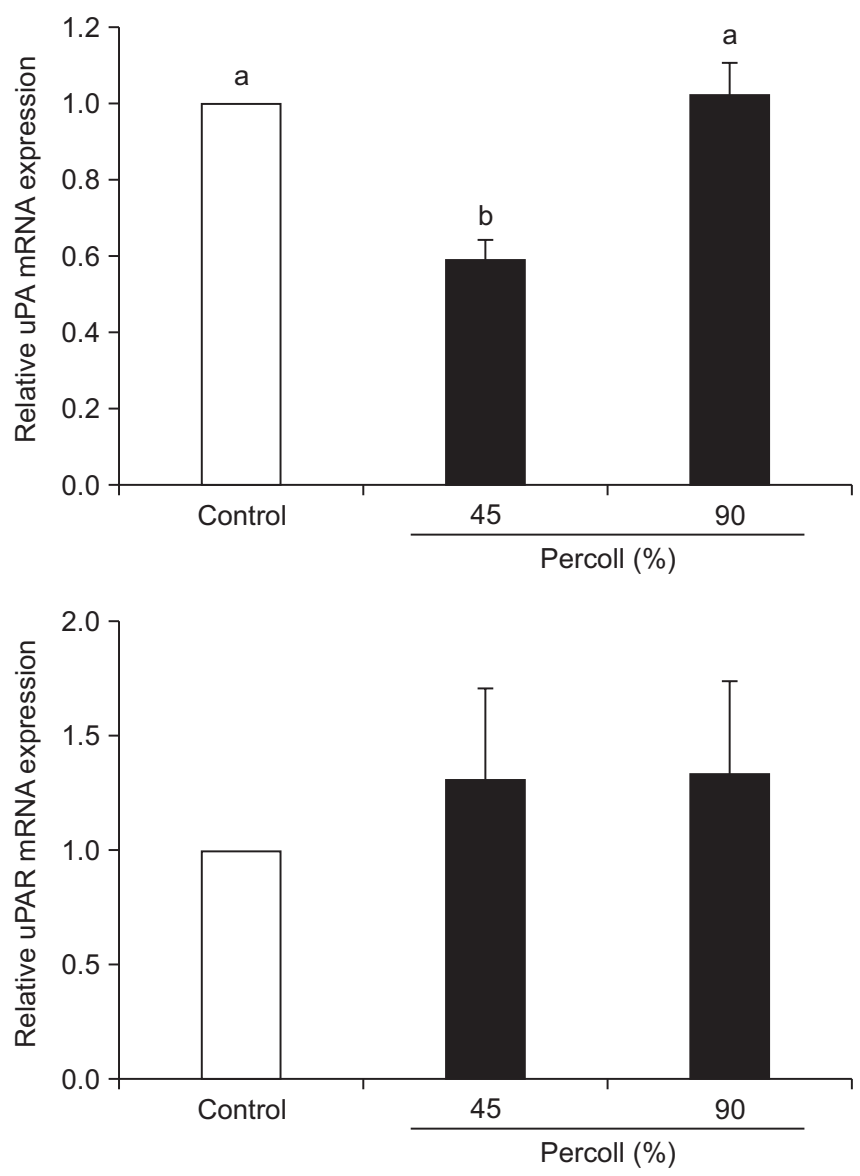

sion of PAs was confirmed after co-culture of sperm for 30 minutes by the Percoll concentration gradient, sperm filtered in $45 \%$ layer inhibited uPA and PAI-1, and sperm isolated in $90 \%$ decreased the expression of $\mathrm{tPA}$ and PAI1 ( $p<0.05$, Fig. 4). the expression of interleukin in Fig. 5 was porcine uterine tissue epithelial cells treated with sperm with different characteristics. However, although there was a tendency to decrease by sperm in the tissues, no significant difference was found (Fig. 5).

\section{Effect of PA on sperm survival rate and acrosome}

When $100 \mathrm{pg} / \mathrm{mL}$ of PAs (uPA, tPA, and PAI) was added to sperm to investigate the effect of PAs in sperm divided by $90 \%$ layer of Percoll, the survival rate and acrosome damage rate that affect fertilization were confirmed with FACs. The groups superinduced uPA and/or I (PAI) were the increased survival rate of sperm and diminished damage (Fig. 6A; $p<0.05$ ). However, there was no significant
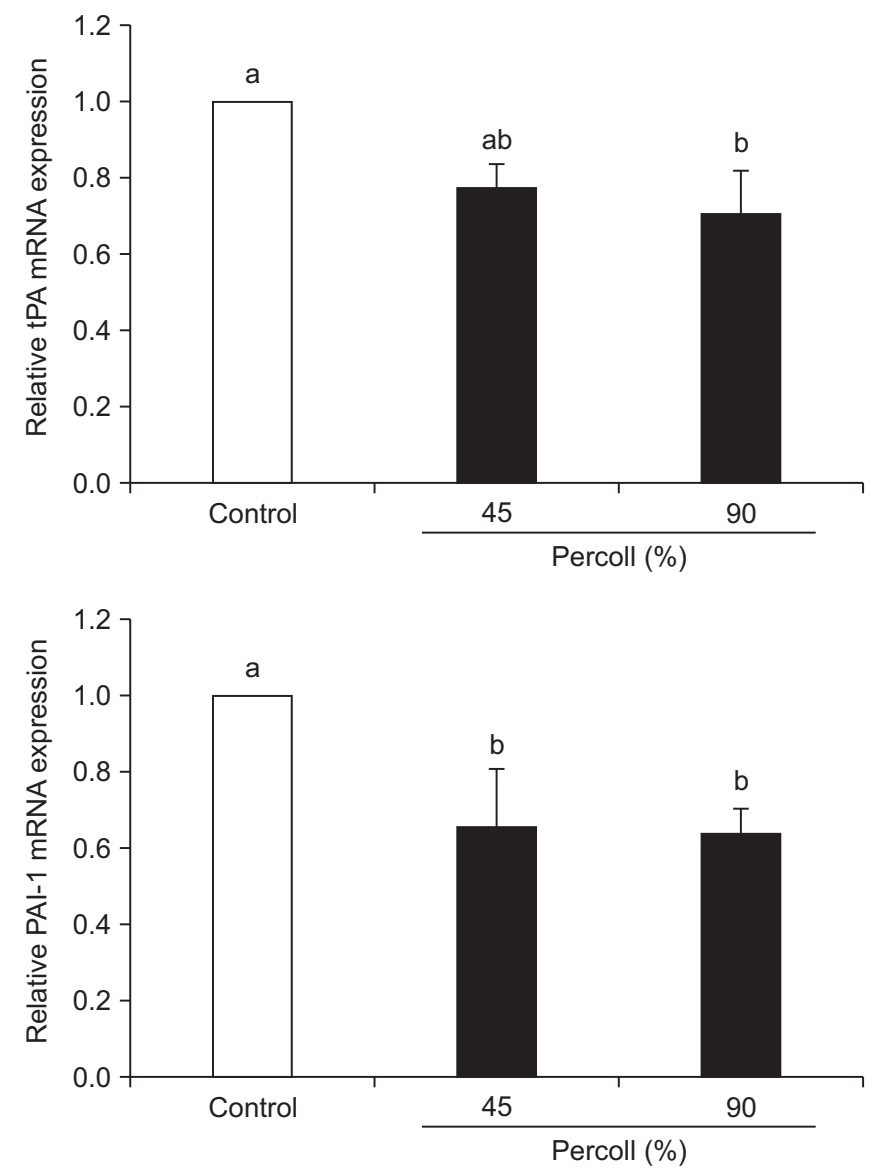

Fig. 4. Change of two types of plasminogen activators (PAs; urokinase-types, uPA; tissus-types, tPA), uPA receptor (UPAR), and types-1 PA inhibitor (PAI-1) mRNA expression by Percoll-separated boar spermatozoa in porcine endometrial tissue epithelial cells. ${ }^{a, b}$ indicates significant difference $(p<0.05)$. 

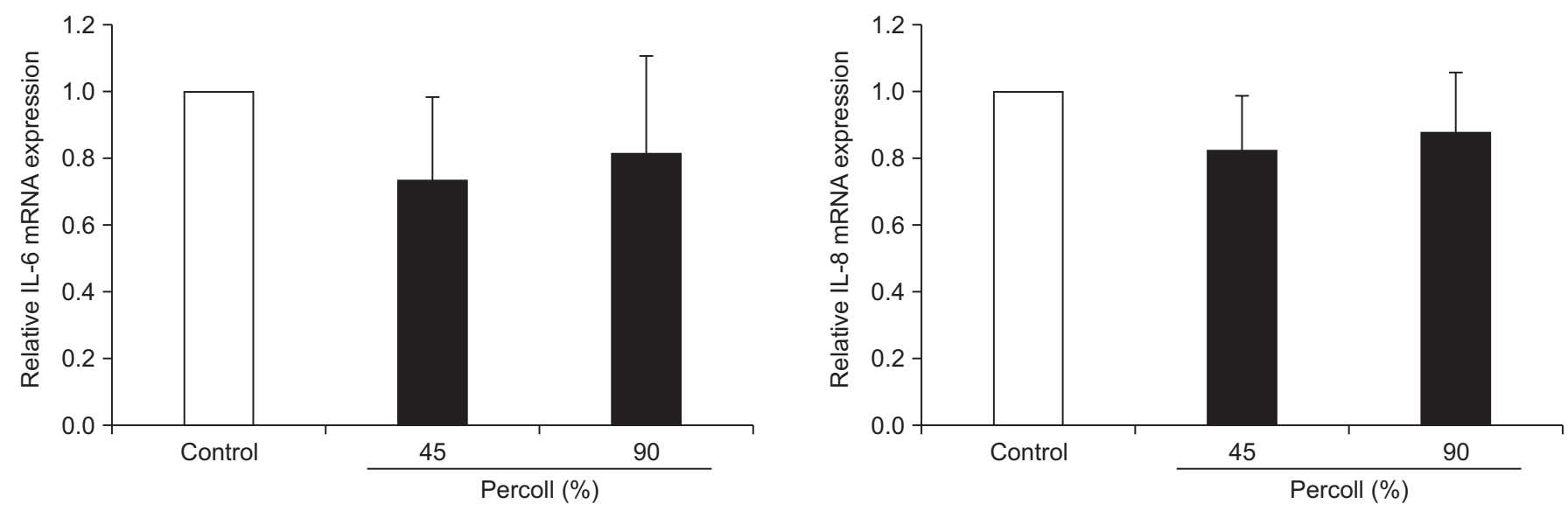

Fig. 5. Change of interleukin-6 and -8 (IL6 and IL8) mRNA expression on Percoll-separated boar spermatozoa in porcine endometrial tissue epithelial cells.

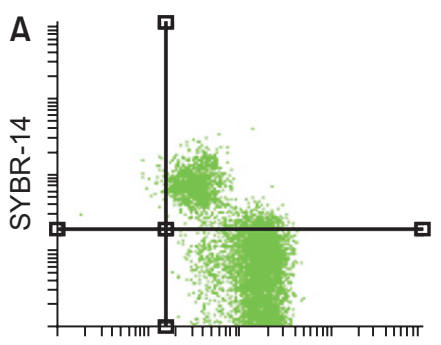

PI

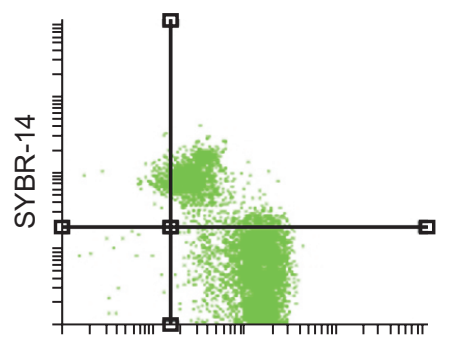

PI

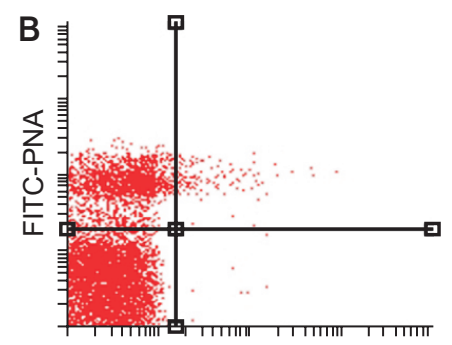

PI

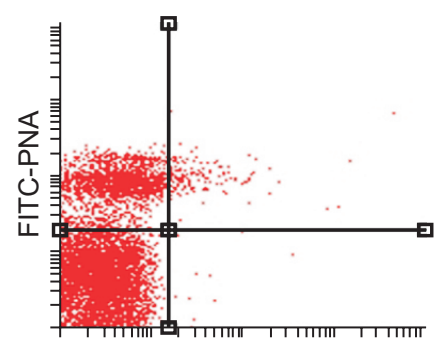

PI
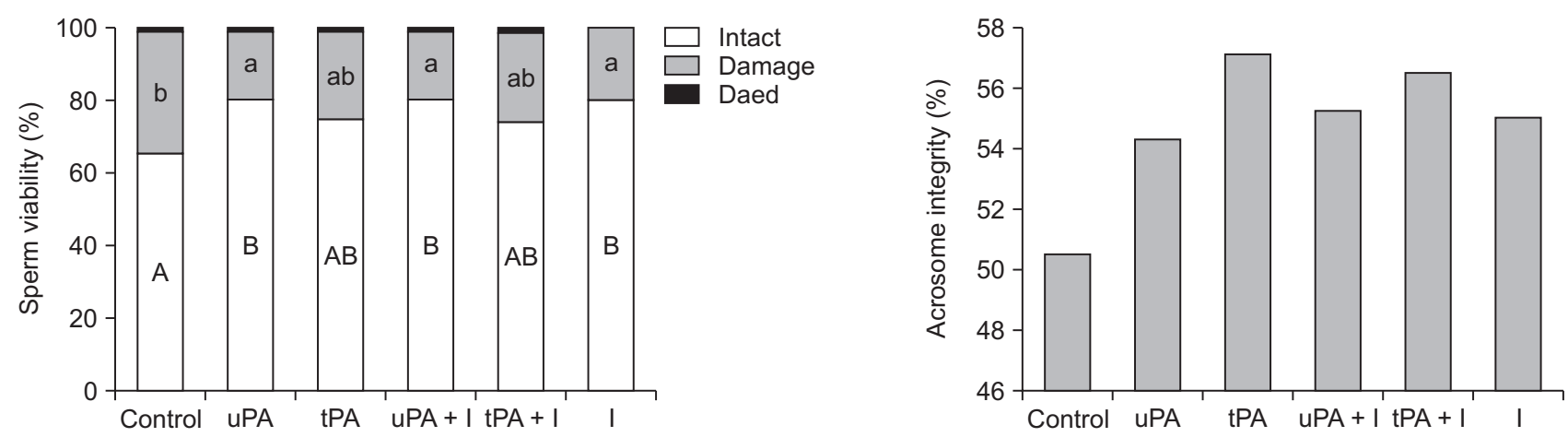

Fig. 6. Effects of 90\% Percoll-separated sperm containing PAs (uPA, tPA and PAl) on viability and acrosome damage. (A) Survival rate of all sperm, (B) The total number of living sperm with acrosome damage. Alphabet indicates significant difference $(p<0.05)$.

difference in survival rate and sperm damage both tPA and $\mathrm{tPA}+\mathrm{I}$ groups. The acrosome damage rate was confirmed in live sperm among all sperm, but no significant difference was confirmed by PAs (Fig. 6B).

\section{DISCUSSION}

In this study, we demonstrated that uPA and PAI improve sperm survival rate, sperm of $45 \%$ Percoll layer decrease $\mathrm{UPA}$, and PAI and TGF- $\beta$ R 1 are change by sperm. Beforetime, When external sperm by paternal pass the uterine, It has been reported that it arouse an immune response in the uterine environment and causes a decrease in sperm viability (Kotilainen et al., 1994; Waberski et al., 2006; López-Úbeda et al., 2017). The previous study identify that sperm divided by Percoll confirmed changes in cytokines and PA-related genes, and it was confirmed that sperm decreased UPA and tPA, and TGF- $\beta$ decline expression in pUECs. In addition, it was confirmed that TGF- $\beta$ decreased PA activity in a volume-dependent manner using SMAD and JNA signaling pathway. Our study identified TGF- $\beta$ and PA-related factors that change when 
sperm with different characteristics due to Percoll adhered to the epithelial cells of porcine uterine tissues and confirmed the effect of PAs on sperm.

The sperm separated by Percoll showed no difference in the adhesion rate, but the sperm with good mobility decreased PA activity. It has been reported that sperm adhesion in oviduct epithelial cells is associated with sperm hyperactivity, and adhesion with cells occurs as the sperm increasing movement of flagella (Ardon et al., 2016). The uterine is an organ which sperm passes, and sperm attached to uterine epithelial cells has higher levels of DNA fragments than other sperm. In addition, it has been reported that when fertilization proceeds by causing DNA damage in bull sperm with gamma rays and $\mathrm{x}$-rays, it causes cell death in fertilized eggs or in the early 2-3 cell phase, thereby inhibiting the formation of blastocysts (Fatehi et al., 2006). Single culture of plasminogen, tPA, and uPA alone did not induce PMN, but it was confirmed that PMN chemotaxis when co-treated with plasmin converted to PA activity (Ryan et al., 1992). It is shown that the production of plasmin during activation of fibrinolysis may play a role in pro-inflammatory mediating PMN aggregation. Therefore, it is decided that it is important to select sperm to reduce PA activity of only sperm sorted in $90 \%$ layer.

In this study, the $45 \%$ sperm had a similar pattern to the $90 \%$ sperm, but there was no significant difference except uPA and TGF- $\beta 2$. These differences are thought to be affected by traits including sperm motility. TGF- $\beta$ which is majority contained in pig's seminal plasma regulates the MAPK or JAK/STAT pathway, which has been reported to be similar to sperm motility signaling (Barranco et al., 2019), and TGF- $\beta$ is associated with sperm motility. In in vitro experiments on the human cervix, male-derived TGF- $\beta 3$ can be seen as the cause of the inflammatory chain reaction after mating by increasing the expression of several genes related to the inflammatory response, these TGF- $\beta$ s are immunosuppressive cytokines that induce immune tolerance in the cervical mucosa and exhibit immunosuppressive properties in semen (Sharkey et al., 2012). Inactive TGF- $\beta$ derived from such semen fluid is changed to an active state by plasmin, $\mathrm{pH}$, thrombospondin-1, $\alpha v \beta 6$ and $\alpha v \beta 8$ (Barranco et al., 2019). In this experiment, the increased expression of TGF- $\beta$ in sperm shows that sperm can induce immune resistance by itself. In fact, it was not possible to classify all of the charac- teristics by the Percoll concentration gradient method, It was confirmed that sperm separated in $45 \%$ layer is nonmotile, but sperm separated in $90 \%$ is found to have the majority of sperm (Parrish et al., 1995). In addition, it was reported that Percoll has higher sperm movement and sperm recovery rate than the swim-up method of classifying sperm (Parrish et al., 1995). Therefore, sperm in this experiment were selected using the Percoll concentration gradient method. Furthermore, Sperm can reduce PA activity by suppressing the expression of tPA in uterine epithelial cells, This PA activity can induce immune actions such as recruitment and induction of neutrophils (Ryan et al., 1992), so it can be expected that it can cause sperm self-protection mechanisms. In addition, in the tissue epithelial cells of this study, interleukin was not affected by sperm. In this experiment, tissue epithelial cells were used to identify the epithelial cells connected to the matrix, but there is a possibility that other effects other than the epithelial cells are attached to the matrix.

In various mammalian species, PAs, including uPA and tPA, are contained in ejaculated sperm and seminal fluid (Smokovitis et al., 1987). The important functions of PAs can also be identified in the uterus. It has been reported that the addition of plasmin to IVF media from bovine sperm increases sperm acrosome integrity and decreases sperm death, and that pigs' mono-spermy can increase when $150 \mu \mathrm{g} / \mathrm{mL}$ of plasmin is treated during fertilization in pigs (Grullón et al., 2013). In addition, there are studies showing that the acrosome response of sperm was increased in a dose and time-dependent manner of plasmin during fertilization of pig sperm (Sa et al., 2006). As a result of this study, sperm increased the viability of sperm in the group contained uPA or/and PAI, and no significant difference was found in acrosome damage. Nevertheless, It has been studied that PAI-1 increases acrosome integrity after freezing at 70 and $140 \mu \mathrm{g}$ (Branco et al., 2017). Also, PAI-1 for sperm acrosomes promotes sperm death (Grullón et al., 2013). Therefore, this experiment was different from those in other studies using the PAI-1 of $100 \mathrm{pg} / \mathrm{mL}$ a small volume to render a minimal effect on sperm. $100 \mathrm{pg} / \mathrm{mL}$ is a very small dose and can be affected by several factors in the actual uterus. The vascular endothelial growth factor (VEGF) typically expressed in the uterus induces uPA, tPA, PAR and PAI-1, and it has been reported that it can increase sperm viability and motility (Ebisch et al., 2008). sperm can be affected di- 
rectly or indirectly through the regulation of PAs by several factors in the uterus.

This study was performed on porcine uterine tissue epithelial cells in order to indirectly confirm the change when sperm enters from the uterus. According to the characteristics of sperm was confirmed both the cytokine and PA activity in porcine epithelial cells. Thus, Percollsparated sperm in $90 \%$ layer show that it can suppress inflammation through increased expression of TGF- $\beta$ and downregulation of PA and IL in epithelial cells compared to $45 \%$ layer Percoll.

\section{CONCLUSION}

Thus, the influence of TGF- $\beta$ on the regulation of the PA system in the uterus was investigated after ejaculation and the expression mechanism of the PA system was established in pig breeding. it is expected to contribute to improving pig productivity by emphasizing the importance of sperm selection.

\section{CONFLICTS OF INTEREST}

No potential conflict of interest relevant to this article was reported.

\section{ACKNOWLEDGEMENTS}

This work was supported by the National Research Foundation of Korea (NRF) grant funded by the Korea government (Ministry of Education) (2019R1A2C1004307). The authors would like to thank Ms. ji-eun for kindly providing the for help with the data analysis.

\section{AUTHOR CONTRIBUTIONS}

\author{
Conceptualization: Su-jin Kim \\ Data curation: Su-jin Kim \\ Formal analysis: Su-jin Kim \\ Funding acquisition: Choon-keun Park \\ Investigation: Su-jin Kim \\ Methodology: Su-jin Kim \\ Project administration \\ Resources: Choon-keun Park \\ Software: Su-jin Kim \\ Supervision: Choon-keun Park
}

\author{
Validation: Choon-keun Park \\ Visualization: Su-jin Kim \\ Writing - original draft: Hee-Tea Cheong \\ Writing - review \& editing: Su-jin Kim
}

\section{AUTHOR'S POSITION AND ORCID NO.}

\author{
SJ Kim, Researcher, \\ https://orcid.org/0000-0003-0046-0069 \\ HT Cheong, Professor, \\ https://orcid.org/0000-0001-8225-0262 \\ CK Park, Professor, \\ https://orcid.org/0000-0003-2786-8814
}

\section{REFERENCES}

Arsina RB and Mukhametova LI. 2014. [Structure and functions of plasminogen/plasmin system]. Bioorg. Khim. 40:642-657. Russian.

Ardon F, Markello RD, Hu L, Deutsch ZI, Tung CK, Wu M, Suarez SS. 2016. Dynamics of bovine sperm interaction with epithelium differ between oviductal isthmus and ampulla. Biol. Reprod. 95:90.

Barranco I, Padilla L, Pérez-Patiño C, Vazquez JM, Martínez EA, Rodríguez-Martínez H, Roca J, Parrilla I. 2019. Seminal plasma cytokines are predictive of the outcome of boar sperm preservation. Front. Vet. Sci. 6:436.

Castellino FJ and Ploplis VA. 2005. Structure and function of the plasminogen/plasmin system. Thromb. Haemost. 93:647654.

Castelo Branco MA, Castelo Branco YNTC, Moraes Junior FJ, Barros FN, Barçante FPS, Carvalho GMC, Melo Evangelista LS, Abreu-Silva AL, Sousa Filho MA, Souza JAT. 2017. Plasminogen activator inhibitor 1 and Antipain preserve acrosome integrity of bovine spermatozoa during cryopreservation. Arq. Bras. Med. Vet. Zootec. 69:1114-1124.

Ebisch IM, Thomas CM, Wetzels AM, Willemsen WN, Sweep FC, Steegers-Theunissen RP. 2008. Review of the role of the plasminogen activator system and vascular endothelial growth factor in subfertility. Fertil. Steril. 90:2340-2350.

España F, Gilabert J, Estellés A, Romeu A, Aznar J, Cabo A. 1991. Functionally active protein $\mathrm{C}$ inhibitor/plasminogen activator inhibitor-3 (PCI/PAI-3) is secreted in seminal vesicles, occurs at high concentrations in human seminal plasma and complexes with prostate-specific antigen. Thromb. Res. 64:309-320.

Fatehi AN, Bevers MM, Schoevers E, Roelen BA, Colenbrander B, Gadella BM. 2006. DNA damage in bovine sperm does not block fertilization and early embryonic development but induces apoptosis after the first cleavages. J. Androl. 27:176188.

Grullón LA, Gadea J, Mondéjar I, Matás C, Romar R, Coy P. 
2013. How is plasminogen/plasmin system contributing to regulate sperm entry into the oocyte? Reprod. Sci. 20:10751082.

Kotilainen T, Huhtinen M, Katila T. 1994. Sperm-induced leukocytosis in the equine uterus. Theriogenology 41:629-636.

Li Q. 2014. Transforming growth factor $\beta$ signaling in uterine development and function. J. Anim. Sci. Biotechnol. 5:52.

López-Úbeda R, García-Vázquez FA, Gadea J, Matás C. 2017. Oviductal epithelial cells selected boar sperm according to their functional characteristics. Asian J. Androl. 19:396-403.

Marey MA, Matsukawa H, Sasaki M, Ezz MA, Yousef MS, Takahashi KI, Miyamoto A. 2020. Bovine oviduct epithelial cells suppress the phagocytic activity of neutrophils towards sperm but not for bacteria in vitro: immunofluorescence and electron microscopic observations. Histol. Histopathol. 35:589-597.

Matás C, Coy P, Romar R, Marco M, Gadea J, Ruiz S. 2003. Effect of sperm preparation method on in vitro fertilization in pigs. Reproduction 125:133-141.

Parrish JJ, Krogenaes A, Susko-Parrish JL. 1995. Effect of bovine sperm separation by either swim-up or Percoll method on success of in vitro fertilization and early embryonic development. Theriogenology 44:859-869.

Rotello RJ, Lieberman RC, Purchio AF, Gerschenson LE. 1991. Coordinated regulation of apoptosis and cell proliferation by transforming growth factor beta 1 in cultured uterine epithelial cells. Proc. Natl. Acad. Sci. U. S. A. 88:3412-3415.

Ryan TJ, Lai L, Malik AB. 1992. Plasmin generation induces neutrophil aggregation: dependence on the catalytic and lysine binding sites. J. Cell. Physiol. 151:255-261.

Sa SJ, Rhee HH, Cheong HT, Yang BK, Park CK. 2006. Effects of plasmin on sperm-oocyte interactions during in vitro fertilization in the pig. Anim. Reprod. Sci. 95:273-282.

Sharkey DJ, Macpherson AM, Tremellen KP, Mottershead DG, Gilchrist RB, Robertson SA. 2012. TGF- $\beta$ mediates proinflammatory seminal fluid signaling in human cervical epithelial cells. J. Immunol. 189:1024-1035.

Smokovitis A, Kokolis N, Alexopoulos C, Alexaki E, Eleftheriou E. 1987. Plasminogen activator activity, plasminogen activator inhibition and plasmin inhibition in spermatozoa and seminal plasma of man and various animal species-effect of plasmin on sperm motility. Fibrinolysis 1:253-257.

Waberski D, Magnus F, Ardón F, Petrunkina AM, Weitze KF, Töpfer-Petersen E. 2006. Binding of boar spermatozoa to oviductal epithelium in vitro in relation to sperm morphology and storage time. Reproduction 131:311-318.

Wada K, Nomura S, Morii E, Kitamura Y, Nishizawa Y, Miyake A, Terada N. 1996. Changes in levels of mRNAs of transforming growth factor (TGF)-beta1, -beta2, -beta3, TGF-beta type II receptor and sulfated glycoprotein-2 during apoptosis of mouse uterine epithelium. J. Steroid Biochem. Mol. Biol. 59:367-375.

Wang L, Guan HT, Tian YH, Xiong CL. 2006. [Urokinase-type plasminogen activator and urokinase-type plasminogen activator receptor in the seminal plasma and sperm of fertile and oligoasthenozoospermia males]. Zhonghua Nan Ke Xue 12:791-793. Chinese. 